\title{
NOTES
}

\section{ADMINISTRATIVE LAW: CONGRESSIONAL GRITICISM OF FTG FOR DECISION IN PENDING CASE HELD TO DEPRIVE ADMINISTRATIVE LITIGANT OF DUE PROCESS}

\begin{abstract}
In Pillsbury, the Fifth Circuit found a denial of due process because a Senate Subcommittee, hearing testimony from members of the Federal Trade Commission, criticized that body for its interpretation of the law applicable to a pending case. While the fact situation is unique, the holding should have significant ramifications for the judicial function of the administrative agencies generally.
\end{abstract}

Althougr the administrative agency ${ }^{1}$ has become an integral aspect of American government, ${ }^{2}$ its role and the ramifications thereof have not been fully integrated conceptually. In Pillsbury Co. v. FTC, ${ }^{3}$ the Fifth Circuit examined the judicial nature of one of these bodies and found that due process of law demands that the judicial function be protected from legislative interference. After the Pillsbury Company, a nationally-known miller and producer of flour products, had acquired two competing businesses in the early fifties, the Federal Trade Commission initiated antitrust proceedings under section 7 of the Clayton Act, claiming that "the effect of such acquisition may be substantially to lessen competition, or to tend to create a monopoly." In remanding the case to the hearing examiner, who had previously dismissed it for lack of evidence, the full Commission held that a prima facie case had been established. 5 However, the Commission rejected the Government's contention that the acquisitions constituted a per se violation of

\footnotetext{
${ }^{1}$ See generally Davis, Administrative Law Treatise (1958); Clark, Administrative Justice, 1960, 13 AD. L. REv. 6 (1960); Fuchs, Fairness and Effectiveness in Administrative Agency Organization and Procedures, 36 IND. L.J. 1 (1960); Massel, The Regulatory Process, 26 LAw \& ConteMp. Prob. 181 (1961); Stone, The Twentieth Century Administrative Explosion and After, 52 CALrF. L. REv. 513 (1964).

2 "They [administrative bodies] have become a veritable fourth branch of the Government, which has deranged our three-branch [sic] legal theories much as the concept of a fourth dimension unsettles our three-dimensional thinking." FTC v. Ruberoid Co., 343 U.S. 470, 487 (1952) (Jackson, J., dissenting).

354 F.2d 952 (5th Cir. 1966).

- Clayton Act $\S 7,38$ Stat. 731 (1914), as amended, 15 U.S.C. $\S 18$ (1964).

¿ Pillsbury Mills, Inc., 50 F.T.C. 555 (1953).
} 
section 7. A mere showing that the merged companies "together control a substantial amount of sales, or that a substantial portion of commerce is affected"6 was in itself insufficient to establish the prohibited tendency to lessen competition; other factors were also essential to that determination. ${ }^{7}$ That opinion, as the first decision of the Commission under the Celler-Kefauver Anti-Merger amendment, ${ }^{8}$ indicated the approach that would be taken in subsequent section 7 cases. $^{9}$

A year and a half later, while Pillsbury was still presenting evidence to the examiner, hearings concerning antitrust matters generally were held in both the House and the Senate. ${ }^{10}$ The chairman of the FTC, Mr. Edward F. Howrey, was asked to appear before these subcommittees to discuss mergers. ${ }^{11}$ Accompanying him were

Id. at 564 .

I"As we see it, amended Section 7 sought to reach the mergers embraced within its sphere in their incipiency, and to determine their legality by tests of its own. These are not the rule of rcason of the Sherman Act, that is, unreasonable restraint of trade, nor are Section 7 prohibitions to be added to the list of per se violations. Somewhere in between is Section 7, which prohibits acts that 'may' happen in a particular market, that looks to 'a reasonable probability,' to 'substantial' economic consequences, to acts that 'tend' to a result." Id. at 569 .

The Commission, in finding a prima facie case, did not rely solely upon the market position which Pillsbury had attained by these acquisitions. It was persuaded also by the general condition of the market, which essentially was one of declining competition, dominated by a few big companies, which had achieved their pre-eminence through mergers. In addition, the Commission took into account the lack of new entries into the market. Id. at 572 .

The per se test which the Commission here rejected was developed under $\$ 3$ of the Clayton Act, 38 Stat. 731 (1914), as amended, 15 U.S.C. $\$ 14$ (1964). See, e.g., Standard Oil Co. v. United States, 337 U.S. 293 (1949); International Salt Co. v. United States, 332 U.S. 392 (1947). Under this test a mere showing that a substantial market had been foreclosed from competition was sufficient to allow the court to grant the appropriate relief. The Government was not further required to show an actual lessening of competition.

${ }^{8}$ Clayton Act $\$ 7,64$ Stat. 1125 (1950), 15 U.S.C. $\$ 18$ (1964).

- The per se test which Pillsbury rejected has not been applied in $\S 7$ cases. Sec, e.g., Brown Shoe Co. v. United States, 370 U.S. 294 (1962); United States v. Bethlehem Steel Corp., 168 F. Supp. 576 (S.D.N.Y. 1958); Handler \& Robinson, $A$ Decade of Administration of the Celler-Kefauver Antimerger Act, 61 Colvm. L. REv. 629 (1961).

${ }_{10}$ See generally Hearings to Study the Antitrust Laws of the United States, and their Administration, Interpretation, and Effect Pursuant to S. Res. 61 Before the Sub. committee on Antitrust and Monopoly of the Senate Committee on the Judiciary, 84th Cong., 1st Sess. (1955) [hereinafter cited as Senate Hearings]; Hearings Before the Antitrust Subcommittee (Subcommittee No. 5) of the House Committee of the Judiciary, 84th Cong., 1st Sess., ser. 3 (1955) [hereinafter cited as House Hearings]. The publication of the ATr'Y GEN. NAT'L CoMm. ANTrTRUst REP. (1955) appears to have been the impetus for these sessions. See Senate Hearings 1 .

${ }^{11} I d$. at 84-85. 
other commissioners and staff members including Mr. Secrest and Mr. Kintner, both of whom were on the Commission in 1960.12 Some of the congressmen expressed displeasure with the tests the Commission was using in merger cases brought under section 7 of the Clayton Act. They feared that the FTG was adopting the rule of reason test developed under the Sherman Act. ${ }^{13}$ In this context the current Pillsbury case was repeatedly used as a pertinent example, by both FTC Chairman Howrey and the committee members. ${ }^{14}$ It soon became very clear that certain members of the Congress believed that the Commission had deviated from congressional intent by rejecting the per se test, and that the Pillsbury acquisition was a perfect example of the type of merger prohibited by law..$^{15}$

12 Present at these hearings with Chairman Howrey were two other commissioners, John W. Gwynne and Robert T. Secrest, as well as certain staff members, including Earl W. Kintner, then Chief Counsel but later Chairman of the Commission and author of the 1960 Pillsbury opinion. Also present was Joseph Sheehy, the Director of the Bureau of Litigation, whose assistant was William Kern, a commissioner in 1960. Thus two of the 1960 commissioners were present at the 1955 hearings and a third commissioner was indirectly exposed to the hearings. See $354 \mathrm{~F} .2 \mathrm{~d}$ at 956; Senate Hearings at 132.

18 "Senator KEFAUVER. I just want to say, as one who has been very much interested in this, Mr. Howrey ... that I have been rather shocked and surprised with the turn that has been given to the amendment to the Clayton Act, having lived with it since the early 1940's.

"It was never the intention of the Judiciary Committee of the House-and I am certain that the same was true over herc-that the new amendment to section 7 of the Clayton Act should be enforced, as you have enforced it, on the basis of Sherman Act tests. It was intended that it was to be enforced on the basis of what the Congress had said about section $\mathbf{3}$ and the other sections of the Clayton Act.

"Here, I cannot be sure, but it seems that you are applying no different treatment to section 7 of the. Clayton Act than has always been applied to Sherman Act cases. That was just not the intent of many of us who were interested in this legislation." Id. at 160.

${ }^{14}$ Chairman Howrey first interjected the Pillsbury decision into the hearings, id. at 97, by observing that its approach had been favorably approved by the Attorney General's report, ATr'y GEN. NAt'L CoMm. ANTITRUST REP. 120-24 (1955). Mr. Howrey's purpose was apparently to show why the per se test was inappropriate to such cases. He again referred to the case in describing the standards that would be used by the FTC in merger litigation. Senate Hearings 124-27. Before the House Subcommittee the Pillsbury case was likewise discussed in connection with the per se test. See House Hearings 2310-11, 2356-57, 2443-53.

${ }^{15}$ Senator Kefauver and Chairman Howrey discussed at some length the extensive durations of antimerger cases. The senator argued that the per se test would shorten them. Mr. Howrey, of course, disagreed. Senate Hearings 139-40. The following remarks are typical:

"Senator KeFAuver. . . . I think" Congress expected that where there was manifestly a lessening of competition, under the amended Clayton Act a merger should not take place.

"Now, here in the Southeast, a section of the country, there is a lessening of com- 
Chairman Howrey belatedly objected to this discussion of a pending case and told the committee that he would consequently disqualify himself from further participation in its consideration. ${ }^{10}$

The hearing examiner continued to receive evidence for nearly five years before the case again came before the Commission. Then in 1960, affirming the decision of the hearing examiner, the Commission ordered Pillsbury to divest itself of the two acquisitions. ${ }^{17}$ In the instant decision in 1966, the Fifth Circuit reversed that holding. The court found that the penetrating discussion of the Pillsbury case which occurred before the Senate Subcommittee constituted an intrusion by the legislature into the judicial function of the Commission and that Pillsbury had therefore been denied due process of law. ${ }^{18}$ It stressed that there must be a fair hearing and moreover that there must be an "appearance of impartiality."10

petition because one firm had 20 and something percent, and the other had 20 and something percent.

"It would seem to me by applying the rule of reason and running the record up to 9,000 pages with more to come, and bringing in every possible economic factor, this, that, and the other, that the Federal Trade Commission is rather taking over the prerogative of congressional intent." Id. at 140 .

In the House, Representative Celler not only reiterated the concern about the time spent in merger cases, but he also made quite clear his opinion that the per se test alone accorded with the congressional intent. House Hearings 2443-44.

16 "Mr. Howrex. Well, I think the question you are asking about the Pillsbury decision is a much greater challenge to judicial processes, because I am sitting as a quasi-judicial officer in that case. That is a much greater challenge to judicial processes than anything I did by participating in tbis committee of the Attorney General.

"Senator KeFAuver. Maybe you should not have answered my questions.

"Mr. Howrex. I think I will disqualify myself in the Pillsbury case for the rest of the case because of the inquiry which you have made about my mental processes in it.

"But let me answer your other question, and I think I should because I do not think I can sit in a quasi-judicial capacity and-I think you have delved too deeply into the quasi-judicial mind in the Pillsbury matter." Senate Hearings 161. See House Hearings 2445.

${ }^{12}$ Pillsbury Mills, Inc., 57 F.T.C. 1274 (1960), rev'd, 254 F.2d 952 (5th Cir. 1966). The Commission clearly did not use a per se approach in rendering its decision. See 57 F.T.C. at $1398-99$ \& n.71.

${ }^{18}$ It is significant to note that in reversing the FTC decision, the court did not assert that the Commission had improperly condueted itself; rather, the court was concerned solely with the congressional interference. "We conclude that the proceedings [the hearings] . . constituted an improper intrusion into the adjudicatory processes of the Commission and were of such a damaging character as to have required at least some of the members in addition to the Chairman to disqualify themselves." 354 F.2d at 963. Thus the court believed that not only Chairman Howrey but other commissioners as well were affected by the probing questions at the hearings. Ibid.

${ }^{19}$ Id. at 964. 
In remanding the case to the Commission, the court intimated that the present commissioners would be sufficiently insulated from the effects of the 1955 hearings such that they could properly dispose of the case. ${ }^{20}$

The court in Pillsbury did not attempt to show in what manner Pillsbury had been injured. Most likely, it was not injured at all, for even as the Commission interpreted the law it seemed clear that the acquisitions were contrary to section $7 .^{21}$ Likewise, the court reached its decision without fully explaining why there was a lack of due process in the proceedings of the Commission. Nonetheless, there are two planes upon which the court's rationale can be examined.

First to be considered is the nature of the procedural guarantees that must be afforded by an administrative body functioning in a judicial capacity. Second is the nature of the relationship between the Congress and the administrative body which adjudicates claims between public and private interests. The court apparently assumed that the agency must afford the same protections extended by a court and further that the agency, at least when pursuing its judicial role, exists independently of the legislature, in the same manner as does a court. Under either assumption the interest to be protected in Pillsbury is the same: trial before an impartial judge.

${ }^{20}$ The manner in which the presently constituted Commission is to handle the case is not at all clear. Presumably, it is to undertake a re-examination of the record as created before the hearing examiner. See id. at 965 . In assuming that the Commission in 1966 was insulated from the effects of the hearing, the court stressed that there had been a change in personnel and further that the law interpreting $\S 7$ had been solidified. Ibid. See note 9 supra.

It is true that there has developed in the law a "mental processes" rule which forbids a revievving court to delve into the administrator's decision-making technique. See, e.g., Gray v. Powell, 314 U.S. 402, 412 (1941); United States v. Morgan, 313 U.S. 409, 422 (1941); Norris \& Hirshberg v. SEC, 163 F.2d 689, 693 (D.C. Cir. 1947), cert. denied, 333 U.S. 867 (1948); Walled Lake Door Co. v. United States, 31 F.R.D. 258, 260 (E.D. Mich. 1962); cf. Fayerweather v. Ritch, 195 U.S. 276 (1904). See also Federal Trade Commission Act $\S 5,38$ Stat. 719 (1914), as amended, 15 U.S.C. $\S 45$ (c) (1964). However, the applicability of this rule to Pillsbury seems inappropriate, for it has not been invoked whenever any improper influence has been revealed. See Shaughnessy v. United States ex rel. Accardi, 349 U.S. 280 (1955); Singer Sewing Mach. Co. v. NLRB, 329 F.2d 200, 206-08 (4th Cir. 1964).

${ }^{21}$ See Pillsbury Mills, Inc., 57 F.T.C. 1274 (1960), rev'd, 254 F.2d 952 (5th Cir. 1966). As the Commission refused to apply a per se test when it again considered the case in 1960, there is no indication that the congressional scolding had its intended effect. See note 16 supra. It can be argued that even though the per se test was not used, the Commission was still pressured to find against Pillsbury. However, the Commission's determination in 1953 that a prima facie case had been established, see text accompanying note 5 supra, would seem to vitiate that contention. 
The regulatory body serves a conglomerate function. It administers the law, establishes regulations pursuant to the law, and decides cases arising under the statutes or its rules, thereby combining executive, legislative and judicial responsibilities. The chief purpose and advantage of this structure is that a body of experts is entrusted with the application of statutes relating to complex areas of governmental regulation. ${ }^{22}$

While agencies have legislative and executive functions, the concern in Pillsbury is only with the judicial function and the procedural due process it demands. ${ }^{23}$ The procedures of a particular administrative body are initially regulated by the creating statute, ${ }^{24}$ the Administrative Procedure Act, ${ }^{25}$ and the rules of procedure of the agency. ${ }^{26}$ The legislation, however, seems only to require a separation of the investigative and the adjudicative functions within the particular agency. ${ }^{27}$ The rules of practice for the Federal Trade

22 There is not absolute agreement on the proper role of these bodies. The most recent focal point of controversy has been whether the judicial function of the agencies should be retained. At the same time there is an emphasis upon increasing the utility of the agencies. See generally 1 Davis, Administrative Law Treatise § 1.04 (Supp. 1965); Fruendzy, The Administrative Agencies (1962); Auerbach, Some Thoughts on the Hector Memorandum, 1960 WIS. L. REv. 183; Cary, Why I Oppose the Divorce of the Judicial Function from Federal Regulatory Agencies, 51 A.B.A.J. 33 (1965); Elman, Rulemaking Procedures in the FTC's Enforcement of the Merger Law, 78 Harv. L. REv. 385 (1964); Hector, Problems of the CAB and the Independent Regulatory Commission, 69 YaLE L.J. 931 (1960); Kintner, The Current Ordeal of the Administrative Process: In Reply to Mr. Hector, 69 YALE L.J. 965 (1960); Shapiro, The Choice of Rulemaking or Adjudication in the Development of Administrative Policy, 78 Harv. L. REv. 921 (1965).

is The nature of the administrative action undertaken determines the procedural rights guaranteed the litigant. Hannah v. Larche, 363 U.S. 420, 440 (1960). Thus, a hearing carried out merely to amass information preparatory to the promulgation of rules or the recommendation of legislation may not require confrontation of witnesses. See id. at 440-52; cf. Superior Oil Co. v. FPC, 322 F.2d 601, 609 (9th Cir. 1963), cert. denied, 377 U.S. 922 (1964); Willapoint Oysters, Inc. v. Ewing, 174 F.2d 676, 694 (9th Cir.), cert. denied, 338 U.S. 860 (1949). However, a hearing which is part of an adjudicatory proceeding would apparently demand that this safeguard be afforded. See Hannah v. Larche, supra at 442; ef. Morgan v. United States, 304 U.S. 1, 18-21 (1938). But cf. Cafeteria \& Restaurant Workers Union v. McElroy, 367 U.S. 886, 894-95 (1961); Bradford v. School District No. 20, 244 F. Supp. 768, 772 (E.D.S.C. 1965).

${ }_{36}$ Federal Trade Commission Act, 38 Stat. 717 (1914), as amended, 15 U.S.C. \$§ $.41-58$ (1964). The essential procedural aspects of the act are contained in 38 Stat. 719 (1914), as amended, 15 U.S.C. $\$ 45$ (1964).

${ }_{20} 60$ Stat. 237 (1946), as amended, 5 U.S.C. $\$ \$ 1001-11$ (1964).

${ }^{20}$ Procedure, Rules of Practice, and Orders of Federal Trade Commission, 16 C.F.R. $\S \S 1.1-.134 ; 2.1-.41 ; 3.1-30$ (1960, Supp. 1965).

${ }^{22}$ Administrative Procedure Act $\S 5,60$ Stat. 239 (1946), as amended, 5 U.S.C. $\S 1004$ (1964). 
Commission are only slightly more explicit by forbidding ex parte communications with a decision maker. ${ }^{28}$

The courts, in refining the procedural guarantees an administrative body must afford in its judicial role, have relied upon the due process concept but have allowed the administrative agencies to adopt lesser standards than those required of the courts. ${ }^{29}$ They have not required a " wholesale transplantation of the rules of procedure, trial, and review which have evolved from the history and experience of the courts." "30 Although no clear guidelines as to procedural due process have been developed by the cases, there is a pervasive emphasis at least upon the general notion of fairness and more particularly upon the appearance of such fairness. ${ }^{31}$

The assumed threat to such fairness in Pillsbury was that the questions asked by the hearings and the pungent criticism of the Commission's interpretation of section 7 would predispose the Commissioners to reach a result adverse to Pillsbury. For administrative litigants, protection against such influence is meager. While the FTC rules prohibit ex parte contacts, they provide no remedy for the potentially resulting harm. ${ }^{32}$ Further, an administrative litigant

${ }^{28} 16$ C.F.R. $\S 4.5$ (Supp. 1965). This provision was made more explicit in 1963. 28 Fed. Reg. 7092 (1963). Still, however, there is no provision for disqualification; ex parte communications are simply forbidden and required to be reported. See generally Sangamon Valley Television Corp. v. FCC, 358 U.S. 49 (1958); Colon, Court and the Commissioner: Ex Parte Contacts and the Sangamon Valley Case, 19 FED. CoM. B.J. 67 (1964-1965); Peck, Regulation and Control of Ex Parte Communications with Administrative Agencies, 76 HARv. L. REv. 233 (1962).

${ }^{20}$ See, e.g., FTC v. Cement Institute, 333 U.S. 683, 705-06 (1948) (agencies are not bound by common law rules of evidence); Lambros v. Young, 145 F.2d 341, 343 (D.C. Cir. 1944) (more informal procedure); United States v. Rasmussen, 222 F. Supp. 430, 438 (D. Mont. 1963) (evidence need not be presented before defendant). See generally 1 Davis, Administrative Law Treatise $\$ 8.03$ (1958).

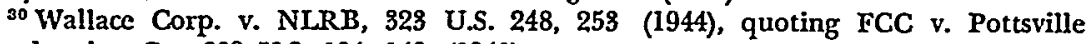
Broadcasting Co., 309 U.S. 134, 143 (1940).

${ }^{31}$ "[A]n administrative hearing . . . must be attended, not only with every element of fairness but with the very appearance of complete fairness." Amos Treat \& Co. v. SEC, 306 F.2d 260, 267 (D.C. Cir. 1962), 76 HARv. L. REv. 831 (1963). See Hornsby v. Allen, 326 F.2d 605, 608 (5th Cir. 1964).

Perhaps In re Murchison, 349 U.S. 133 (1955), best illustrates the meaning of such a standard. There the judge who heard the contempt proceedings which arose out of a grand jury investigation was also the sole member of the "one-man grand jury" which had issued the contempt citation. The Court, holding that such a procedure violated due process, noted that "our system of law has always endeavored to prevent even the probability of unfairness." Id. at 136. Cf. Offutt v. United States, 348 U.S. 11 (1954).

${ }^{38}$ See note 28 supra. However, in Sangamon Valley Television Corp. v. United States, 269 F.2d 221 (D.C. Cir. 1959), the court held that ex parte contacts between the Commissioners and one interested in the assignment of a television channel 
can seldom successfully assert a violation of due process merely because a member of a commission had in the past adversely commented on the activity presently subject to review. ${ }^{33}$ The related question of the personal bias of the decision maker is confounded by the lack of a statutory disqualification device. ${ }^{34}$ Consequently, in several cases a rule of necessity has been applied allowing the allegedly biased personnel to decide the dispute since no other body is competent to do so. ${ }^{35}$

As the protection afforded against outside influence upon the decision making process of an administrative judge is minimal, a rationalization of Pillsbury under such an analysis falters. While the congressional investigation here may be likened to an ex parte

vitiated the determination of the FCC, thus requiring a reopening of the proceed. ing. See generally Peck, supra note 28.

${ }^{3 s}$ See, e.g., FTC v. Cement Institute, 333 U.S. 683, 702.03 (1948) (prior report to Congress that basing point system was unfair); United States v. Morgan, 313 U.S. 409, 421-22 (1941) (public criticism of court decision pertinent to case); Gilligan, Will \& Co. v. SEC, 267 F.2d 461, 468 (2d Cir.), cert. denied, 361 U.S. 896 (1959), 45 VA. L. REv. 1053 (prior press release that conduct subsequently at issue violated law); National Lawyers Guild v. Brownell, 126 F. Supp. 730, 733 (D.D.C. 1954) (public statement of intent to register Guild as Communist front); Montana Power Co. $v$. Public Service Comm'n, 12 F. Supp. 946, 948-49 (D. Mont. 1935) (campaign promise to take action here at issue). Contra, Texaco, Inc. v. FTC, 336 F.2d 754, 759.60 (D.C. Cir. 1964), vacated and remanded on other grounds, 381 U.S. 739 (1965) (speech prior to appointment to commission); $c f$. United States ex rel. Accardi v. Shaughnessy, 347 U.S. 260 (1954), in which the Court held that a potential deportee could assert that the decision by the Board of Immigration Appeals had been dictated by the Attorney General, inasmuch as there had been circulated among the Board a statement by the Attorney General that the relator was an "unsavory character" and should be deported. Id. at 264. The Court noted that while the Board was subordinate to the Attorney General, it was nonetheless required to exercise its own discretion in cases before it. $I d$. at 266-67. See generally Comment, 13 VAND. L. REv. 712, 720-22 (1960).

36 In the federal district courts, litigants can by filing the proper affidavit recuse and have removed judges with a personal bias in the case. 28 U.S.C. $\S 144$ (1964). See generally Berger v. United States, 255 U.S. 22 (1920); Loew's, Inc. v. Cole, 185 F.2d 641 (9th Cir. 1950), cert. denied, 340 U.S. 954 (1951); Eisler v. United States, 170 F.2d 273 (D.C. Cir. 1948), cert. dismissed, 338 U.S. 883 (1949); United States v. Gilboy, 162 F. Supp. 384 (M.D. Pa. 1958); Note, Disqualification of Judges for Bias in the Federal Courts, 79 HARv. L. REv. 1453 (1966). In Texaco, Inc. v. FTC, 336 F.2d 754 (D.C. Cir. 1964), vacated and remanded on other grounds, 381 U.S. 739 (1965), the court held that Texaco was denied due process in an administrative hearing because Commissioner Dixon, who had publicly attacked the practice in issue, had participated in the decision. Id. at 760. The case indicates that even without a statutory disqualification device, a decision maker can be forced to recuse himself.

${ }^{35}$ E.g., FTC v. Cement Institute, 333 U.S. 683, 701 (1948); Federal Home Loan Bank Bd. v. Long Beach Fed. Sav. \& Loan Ass'n, 295 F.2d 408, 408 (9th Cir. 1961); Montana Power Co. v. Public Service Comm'n, 12 F. Supp. 946,949 (D. Mont. 1935). But cf. Texaco, Inc. v. FTC, supra note 34. 
contact, beyond disclosure there is no remedy provided for that threat to an impartial hearing. Further, there appears to have been no claim of bias in the instant case. Even if the argument had been presented, the rule of necessity would probably have been applied. Finally, while the facts may substantiate the evil inherent in prior comment and expression of opinion, there appears to be no relief from that possible harm.

The court, however, did not make any examination of the procedural guarantees owed to a party in Pillsbury's position. It considered instead the isolation of the administrative agency from the Congress and sought "to preserve the integrity of the judicial aspect of the administrative process." 36 It is curious that the Pillsbury court was extremely concerned with the mere possibility of harm while other courts have easily discounted actual injury created by influence on administrative judges. This inconsistency suggests that the thrust of this opinion goes to the nature of the administrative body rather than to the protections that such a body must afford.

The administrative agencies are creatures of Congress. The ramifications of that origin, however, are uncertain. The ability of the legislature to probe into the judicial operations of an administrative body has been examined only cursorily by the commentators $^{\mathbf{3 7}}$ and not approached by the courts directly until Pillsbury. Congress surely has a legitimate interest in determining whether the laws it passes are appropriately executed by these regulatory bodies. Accordingly, there have been established both special watchdog committees ${ }^{38}$ and oversight duties in existing committees. ${ }^{39}$

\footnotetext{
3035 F.2d at 964.

${ }^{37}$ See generally Report on Regulatory Agencies to the President-Elect, 86th Cong., 2D SEss. 33-34 (Comm. Print 1960); Committee on Organization of the Ex. Ecutive BRANGH OF GOVERNMENT, TASK FORCE REPORT ON REgulatory CoMmissions app. N (1949) [hereinafter cited as TASK FORCE REPORT]; Broden, Legislative and Executive Oversight of the Administrative Process, 26 ICG PRAC. J. 768 (1959); Committee on Administrative Law, Congressional Oversight of Administrative Agencies, 5 REcord of N.Y.C.B.A. 11 (1950); Hall, Responsibility of President and Congress for Regulatory Policy Development, 26 LAW \& Contenp. Prob. 261, 278-80 (1961); Heady \& Linenthal, Congress and Administrative Regulation, 26 LAW \& CONTEMP. PrOB. 238 (1961); Legislature-Agency Disagreements Concerning the Construction of Regulatory Statutes, 36 A.B.A.J. 859 (1950); Melville, Legislative Control Over Administrative Rule Making, 32 U. Cinc. L. REv. 33 (1963); Newman \& Keaton, Congress and the Faithful Execution of Laws-Should Legislators Supervise Administrators?, 41 CALrF. L. REv. 565 (1953).

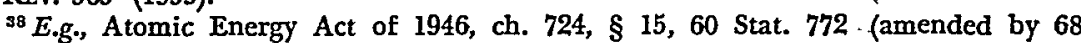
Stat. 956 (1954), 42 U.S.C. $\$ \S 2251-57$ (1964)); Labor Management Relations Act
} 
By these devices the lawmakers may keep informed as to the adequacy of existing laws, the need for amendments, and the quality of the body which it has created to administer the laws in question. However, when these committees, or Congress itself, seek not only information but a control over the decision making pattern of the agency, then the regulatory body would seem to be little more than an arm of the particular congressional committee. ${ }^{40}$ Such a result, however, seems fully inconsistent with congressional intent and constitutional requirements. ${ }^{41}$

In creating and developing the administrative instrument, in this instance the FTC, Congress established a new and separate body which would have broad discretion in executing the duties delegated to it. ${ }^{42}$ Subsequent enactments such as the Administrative

$\$ \$ 401-07,61$ Stat. 160 (1947). See generally Melville, supra note 37, at 37; “Watchdog Committees" in the 80th Congress, 34 A.B.A.J. 726 (1948).

30"To assist the Congress in appraising the administration of the laws and in developing such amendments or related legislation as it may deem necessary, each standing committee of the Senate and the House of Representatives shall exercise continuous watchfulness of the execution by the administrative agencies concerned of any laws, the subject matter of which is within the jurisdiction of such committee; and, for that purpose, shall study all pertinent reports and data submitted to the Congress by the agencies in the executive branch of the Government." Legislative Reorganization Act of 1946, § 136, 60 Stat. 832, 2 U.S.C. $\S 190 d$ (1964).

10 This dichotomy of function was disputed with reference to the Pillsbury case:

"Mr. Keating. I do not think this committee has got any business telling the Federal Trade Commission how to run their shop or how they should conduct their lawsuit or prepare their cases for trial. I think it is going way wide of the mark of anything I thought we were set up to do.

"The Chairman. I do not agree with the gentleman. I think we have a right to know how our act is being carried out." House Hearings 2453.

"[G]iven no impropriety, the rationality of their [regulatory agencies] decisions or their attitude towards the handling of pending causes, even though some of them may not yet bave reached the adjudicatory stage, should not be subject to inquiry. Their independence in this respect should be as much respected as that of the judges." Report on Regulatory Agencies, op. cit. supra note 37, at 34 .

"It is clear that legislative committees ought not suggest how the agency should decide particular cases or issues pending in those cases-any more than the legislature would presume to suggest to a court that it should decide a particular case for the plaintiff or defendant." Committee on Administrative Law, supra note 37, at 15. Cf. United States v. Morgan, 313 U.S. 409, 422, (1941).

1 See note 44 infra.

12 While the FTC may have originally been conceived as little more than an auxiliary to the Justice Department and as an expert advisor to the Congress, it was nonetheless to be an "independent" body like the ICC capable of being given more power at a later time. See S. REP. No. 597, 63d Cong., 2d Sess. 8-12 (1914). "Such work [building up a body of administrative law] must be done by a board or commission of dignity, permanence, and ability, independent of executive authority, ex. cept in its selection, and independent in character." Hearings Pursuant to S. Res. 98 Before the Senate Committee on Interstate Commerce, 62d Cong., 1st Sess. 11 (1911). See generally Daish, The Federal Trade Commission, 24 YALE L.J. 43 (1914). The 
Procedure Act reinforce the view that the administrative agencies are more than appendages of Congress. ${ }^{43}$ Further, the nature of the legislative process argues against a contrary notion. The Congress has authorized a judicial function in the agency; yet, if it dictates the decisions of that agency, the legislature itself is exercising a judicial function. ${ }^{4}$ Aside from all these objections to the dilution of the independent judicial power in the agencies is the simple observation that it is not necessary, for if Congress dislikes the interpretation that is being given to a particular statute, it can amend the law rather than subvert the independence of the agency.

By preserving the independence of the FTC's judicial function, Pillsbury accomplishes two results. It militates against the danger of a determination of the disputed issue by a few members of a congressional committee who have not heard all the evidence and who are predisposed to one result. Moreover, Pillsbury forbids Congress to give an interpretation of the law applicable to a suit after it has been commenced. ${ }^{45}$ Although the rationale which produces these

power of the FTC was increased in 1938. See Act of March 21, 1938, ch. 49, § 3, 52 Stat. 111.

The regulatory commissions are generally referred to as "independent" which seemis intended to connote that the personnel are beyond the removal power of the president. See Jaffe, Judicial Control of Administrative Action 3, 21 (1965); TASK Force RePORT 12, 14.

"Implicit in the recommendation for legislation to regulate the procedures of the administrative agencies was the realization that these bodies were largely free to pursue their own methods of operation. See H.R. REP. No. 1980, 79th Cong., 2d Sess. 7-18 (1946). "The purpose of the bill is to assure that the administration of government through administrative officers and agencies shall be conducted according to established and published procedures which adequately protect the private interests involved, the making of only reasonable and authorized regulations, the settlement of disputes in accordance with the law and the evidence, the impartial conferring of authorized benefits or privileges, and the effectuation of the declared policies of Congress in full." Id. at 18.

"The exercise of the judicial function by the legislature is proscribed by the theory of separation of powers as incorporated in the Constitution. See Kilbourn v. Thompson, 103 U.S. 168, 190-91 (1880); cf. O’Donoghue v. United States, 289 U.S. 516, 530-34 (1933); J. W. Hampton, Jr. \& Co. v. United States, 276 U.S. 394, 406-07 (1928). See generally THE FEDERALIST Nos. 47-48 (Madison), 81 (Hamilton). "There is always the temptation in this system for members of the staff or of the committee to intrude into the actual administration of the statute and to attempt to influence specific policies or decisions of the commission through informal suggestion. Any such development would appear inconsistent with the traditional separation of powers and would tend toward less responsibility instead of more." TASK FORCE REPORT 37.

${ }^{*}$ In People ex rel. Mutual Life Ins. Co. v. Board of Supervisors, 16 N.Y. 424 (1857), the legislature, after the suit had been commenced, passed an act declaring what it deemed the proper construction of the statute applicable in the litigation. The court held that it was not bound by the subsequent legislation and noted that "the legislature has no judicial power, and cannot upon any pretense interpose its 
results is obscure, the court has suggested a standard which may give some insight into the precedential quality of the decision: "[W]e become concerned with the right of private litigants to a fair trial and, equally important, with their right to the appearance of impartiality . ..."40

Such a standard, which has been alluded to in previous dicta, ${ }^{47}$ accomplishes two objectives. It allows the court to reverse the decision of an administrative body in circumstances where, although the court cannot isolate a specific manifestation of prejudice, there is a substantial likelihood of its existence. Additionally, by concentrating upon appearance and not merely effects, this test, when used as a guide post by the agency or congressional committee, should constitute a preventive force against practices potentially prejudicial to parties to administrative proceedings. For this purpose it does not serve as well as would a more absolute rule which could fully proscribe certain conduct. Nonetheless, even if the committee members and the commissioners are unable to determine the requirements of the rule in a particular factual situation, they will at least be conscious that a standard does exist. ${ }^{48}$ They therefore hopefully may be less disposed to pursue harmful dialogue.

While Pillsbury appears to be founded on this appearance test more than upon any other basis, the use of that standard reflects the court's concept of an independent judicial role for the admin-

authority respecting questions of interpretation pending in the courts." Id. at 432. Accord, Personal Finance Co. v. United States, 86 F. Supp. 779 (D. Del. 1949).

A change in the understanding of the constitution may often be retroactive. Compare United States ex rel. Durocher v. LaVallee, 390 F.2d 303 (2d Cir.), cert. denied, 377 U.S. 998 (1964), with Linkletter v. Walker, 381 U.S. 618 (1965). See also Bender, The Retroactive Effect of an Overruling Constitutional Decision: Mapp v. Ohio, 110 U. PA. L. Rev. 650 (1962). See generally Note, 41 Notre DAME LAw. 206 (1965). A change in statutory law, however, is generally only prospective. See, e.g., NLRB v. Clark, 176 F.2d 341 (9d Cir. 1949). But cf. Great No. Ry. v. Sunburst Oil \& Refining Co., 287 U.S. 358 (1982). Of course, changes in criminal law detrimental to an accused or one convicted are forbidden by the prohibition on ex post facto laws. U.S. Const. art. 1, §§ 9-10; see Calder v. Bull, 3 U.S. (3 Dall.) 386 (1798). However, changes in the criminal law of a beneficial nature are generally available to the accused and the convicted. See 34 N.Y.U.L. Rev. 1138, 1936 \& nn. 13-14 (1959). But cf. Annot., 95 A.L.R.2d 1265, 1290 (1964).

10354 F.2d at 964. (Emphasis added.)

17 See Amos Treat \& Co. v. SEC, 306 F. 2d 260, 267 (D.C. Cir. 1962), 76 Harv. L. REv. 831 (1968); cf. In re Murchison, 349 U.S. 193, 196 (1955); Offutt v. United States, 348 U.S. 11, 17 (1954); Berger v. United States, 255 U.S. 22, 85-86 (1921); Whitaker v. McLean, 118 F.2d 596 (D.C. Cir. 1941) (per curiam).

${ }^{18} \mathrm{It}$ was apparent even at the Senate hearings that Chairman Howrey felt that he had acted prejudicially to Pillsbury. Senator Kefauver was equally conscious of the impropriety. See note 16 supra. 
istrative agency. However, that assumption as embodied in the appearance test does not accord with the general line of authority exempting administrative bodies from rigorous due process limitations. Consequently, the case stands alone. Future litigation concerning the impartiality of an administrative panel will be confronted by the result and the broad test of Pillsbury. The unique character of the fact situation and the sweep of the appearance test Pillsbury espouses may, however, provide ready handles to distinguish it. 